BIOLOGICAL SCIENCES

\title{
Lecithochirium monticellii digenetic trematode parasites of Trichiurus lepturus (Actinopterygii) from the state of Rio de Janeiro, Brazil, with notes on its taxonomy
}

\author{
LUMA F. FRANÇA, MARCELO KNOFF, MICHELLE C.G. DA FONSECA, DELIR C. GOMES, \\ MICHELI S. FERREIRA, NILZA N. FELIZARDO, SÉRGIO C. DE SÃO CLEMENTE \& \\ DANUZA P.B.G. DE MATTOS
}

\begin{abstract}
Trichiurus lepturus (Actinopterygii, Perciformes) is a commercially and economically important fish. A total of 60 specimens of this cutlassfish were collected of the coast the municipalities of Niterói and Cabo Frio, state of Rio de Janeiro, Brazil. The fish were measured, necropsied, filleted and had their organs investigated for digenetic trematodes. Taxonomic identification was based on morphological and morphometric characters. The specimens of $T$. lepturus were parasitized with adult specimens of Lecithochirium monticellii. Parasite indices of prevalence, intensity, mean intensity, abundance, mean abundance, range of infection, and site of infection of parasitic species were evaluated. Notes on the taxonomy of the parasite were also included. This is the first report of L. monticellii parasitizing T. lepturus in Brazil.
\end{abstract}

Key words: Cutlassfish, Hemiuridae, Lecithochiriinae, Lecithochirium monticellii, Trematoda, Trichiurus lepturus.

\section{INTRODUCTION}

The cutlassfish Trichiurus lepturus, L. 1758 (Actinopterygii, Perciformes), is considered a benthopelagic species and is found on continental shelves and underwater slopes from the surface to $2000 \mathrm{~m}$ deep in tropical and temperate waters that are not of low salinity (Nakamura \& Parin 1993, Martins \& Haimovici 1997). Considered one of the six species with the highest volume of fish landings in the world (Martins \& Haimovici 2000, FAO 2005, Martins et al. 2005, Chiou et al. 2006, Bittar et al. 2008), T. lepturus has great commercial importance in the state of Rio de Janeiro (Meyer \& Smale 1991, Martins \& Haimovici 1997, Figueiredo \& Menezes 2000).
Helminth parasites (Platyhelminthes, including digenetic trematodes, monogenoids, and trypanorhynch and "tetraphyllid" cestodes; anisakid and raphidascaridid nematodes; and acanthocephalans) of T. lepturus have been reported in specimens off the coast of the state of Rio de Janeiro (Barros \& Amato 1993, São Clemente et al. 1995, Silva et al. 2000a, b, Carvalho \& Luque 2009, 2011, Mattos et al. 2013, Borges et al. 2015).

Parasites of the genus Lecithochirium Lühe 1901 (Hemiuroidea, Hemiuridae, Lecithochiriinae) are commonly observed in the stomach and intestine of marine teleost fish throughout the world (Yamaguti 1971, Bray 1991, Gibson et al. 2002, Shih et al. 2004, Kohn 
et al. 2007, Al-Zubaidy 2010, Feki et al. 2016, Claxton et al. 2017). Species of this genus have been described as having complex morphology, with variation in, and different combinations of, internal and external structures that provide specific taxonomic characteristics. As a result, a large number of species have been described for the genus. However, some reviews have considered such differences to be intraspecific variation and thus proposed synonimizing several of the names (Manter 1934, 1954, Linton 1940, Skrjabin \& Guschanskaja 1955, Nasir \& Diaz 1971, Yamaguti 1971, Bray 1991).

Six species of Lecithochirium were recorded parasitizing marine teleost fish of the Brazilian coast: L. imovacus (Looss 1907) Skrjabin \& Guschanskaja 1955, L. manteri Freitas \& Gomes 1971, L. microstomum Chandler 1935, L. monticellii (Linton 1898) Skrjabin \& Guschanskaja 1955, L. perfidum Gomes, Fábio \& Rolas, 1972, L. texanum (Chandler, 1941) Manter, 1947 and L. zeloticus (Travassos, Freitas \& Bührnheim 1966) Nasir \& Diaz 1971 (Kohn et al. 2007).

The present study aimed to taxonomically identify specimens of digenetic trematodes in T. lepturus commercialized along the coast of the state of Rio de Janeiro, Brazil, and to present their parasite indices of prevalence, mean intensity, mean abundance, range of infection and infection sites.

\section{MATERIALS AND METHODS}

Between June 2017 and February 2018 a total of 60 specimens of Trichiurus lepturus, (74 - $142 \mathrm{~cm}$ total length, 0.400 - $3.0 \mathrm{~kg}$ weight) were obtained in small markets selling fish caught from offshore of the municipalities of

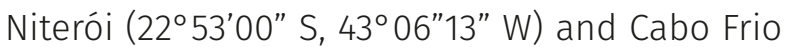
$\left(22^{\circ} 52^{\prime} 46^{\prime \prime} \mathrm{S}, 42^{\circ} 01^{\prime \prime} 07^{\prime \prime} \mathrm{W}\right)$, in the state of Rio de Janeiro, Brazil. The specimens were transported in isothermal boxes with ice to Laboratório de
Parasitologia, Instituto Biomédico, Universidade Federal Fluminense, in the municipality of Niterói, state of Rio de Janeiro. The specimens were identified to species according to Figueiredo \& Menezes (2000), and then necropsied for analysis of stomach contents and the intestines, which revealed the presence of a species of digenetic trematode. The helminths were fixed with AFA, stained with Semichon carmine or Delafield hematoxylin and whole mounted in Canada balsam (Knoff \& Gomes 2012), and then analyzed using a Zeiss Axiophot brightfield microscope. Measurements (in $\mathrm{mm}$ ) were made with the aid of an Olympus BX-41 brightfield microscope with an ocular micrometer. Measurements are provided as ranges followed by means in parentheses. Taxonomic classification of the parasites followed Gibson et al. (2002). Voucher specimens were deposited in the Helminthological Collection of the Oswaldo Cruz Institute (CHIOC), FIOCRUZ, Rio de Janeiro, RJ, Brazil. Parasitological terminology followed Bush et al. (1997).

\section{RESULTS}

Forty-three of the 60 specimens of T. lepturus analyzed were parasitized with a total of 929 adult specimens of a species of digenetic trematode. The majority of specimens were found alive and exhibiting high motility. The parasites included some immatures and exhibited pronounced variability in size, indicating continuous recruitment. The parasites were identified as follows:

- Hemiuridae Looss, 1899

- Lecithochiriinae Lühe 1901

- Lecithochirium Lühe 1901

- Lecithochirium monticellii (Linton 1898) Skrjabin \& Guschankaja 1955 (Figures 1ab, 2a, b) 


\section{General description}

Morphological features were observed on 40 whole mounts specimens. Body elongate, subcylindrical with smooth tegument. Preoral lobe present. Ecsoma well developed, retracted in some specimens. Oral sucker subglobular, subterminal. Ventrocervical groove present with thickened walls. Pharynx subglobular, smaller than oral sucker, partly overlying oral sucker. Ventral sucker subglobular, developed, larger than oral sucker, pre-equatorial. Ceca lined with thick epithelium, entering ecsoma. Testes two, rounded, smooth, slightly diagonal, posterior and close to ventral sucker, preovarian, intercecal, in largely coincident fields, in distant zones in larger specimens, in smaller specimens the posterior portion of the anterior testicle coincides with the anterior portion of the posterior testicle, margins often obscured by uterine loops. Vas efferens uniting to vas deferens close to medium margin of ventral sucker. Vas deferens, small, uniting to seminal vesicle. Seminal vesicle tripartite, partially overlapping anterior margin of ventral sucker, with thick wall, posterior portion largest, anterior portion smallest, uniting to ejaculatory duct. Ejaculatory duct small, slightly sinuous, sometimes swollen in its proximal, median and even distal portion, appearing as an external ejaculatory vesicle, surrounded by numerous prostatic cells, forming a well- developed pars prostatica. Ejaculatory duct uniting to sinus sac meeting ejaculatory vesicle. Sinus sac 'separogermiductus-type', oval, well developed, thick walled, containing well-developed ejaculatory vesicle (sometimes described as a prostatic vesicle), and a long muscular, protrusible, hermaphroditict duct that opens in the genital pore. Genital pore median, at or slightly posterior to pharyngeal level. Ovary rounded, smooth, post-testicular, intercecal, at mid-hindbody or more posteriorly, at some distance from posterior testis, in the same field of testes but in separated zones, margins often obscured by uterine loops. Uterus descending into postvitelline space, reaching ecsoma and filling most of the hindbody, metraterm entering sinus sac ventrally, joining male duct slightly anterior to ejaculatory vesicle. Vitellaria paired, contiguous, overlapping posterior portion of ovary, one tri- and one quadri-lobed with lobes somewhat longer than wide. Eggs small and operculate, numerous. Excretory pore terminal, excretory duct bifurcating posterior to ventral sucker, arms unite dorsally to oral sucker.

\section{Measurements}

Measurements for 10 of the larger specimens: body 2.02-4.02 (2.84) long by 0.27-0.52 (0.40) wide at level of ventral sucker. Ecsoma 0.15-1.52 (0.58) long by 0.22-0.42 (0.28) wide. Oral sucker 0.06-0.14 (0.10) in diameter. Ventral sucker 0.210.41 (0.23) in diameter. Sucker ratio 1:1.95-2.41. Anterior testis $0.05-0.20$ (0.12) long by $0.05-0.19$ (0.09) wide. Posterior testis 0.06-0.21 (0.14) long by 0.06-0.17 (0.11) wide. Sinus sac, 0.05-0.10 (0.07) long. Seminal vesicle, 0.11-0.34 (0.22) long. Ovary, 0.05-0.22 (0.11) long by 0.06-0.20 (0.13) wide. Distance from posterior testis to ovary 1/5-1/6 of body length. Eggs 22.5-27.5 (24.2) $\mu \mathrm{m}$ long by 10-12.5 (10.6) $\mu \mathrm{m}$ wide.

Measurements for 10 of the smaller specimens: body, 1.02-1.90 (1.40) long by 0.220.50 (0.35) wide at level of ventral sucker. Ecsoma retracted $0.17-0.50(0.25)$ long by $0.12-0.22(0.17)$ wide. Oral sucker 0.07-0.13 (0.10) in diameter. Ventral sucker 0.15-0.31 (0.26) in diameter. Sucker ratio 1:1.73-2.10. Anterior testis 0.05-0.13 (0.08) long by $0.05-0.11$ (0.09) wide. Posterior testis 0.06-0.15 (0.08) long by 0.06-0.13 (0.08) wide. Sinus sac, 0.02-0.10 (0.06) long. Seminal vesicle 0.05-0.17 (0.10) long. Ovary, 0.05-0.13 (0.07) long by $0.06-0.15$ (0.10) wide. Distance from posterior testis to ovary $1 / 15$ of body length. Eggs $15-27.5$ (18.2) $\mu \mathrm{m}$ long by 10-12.5 (10.2) $\mu \mathrm{m}$ wide. 

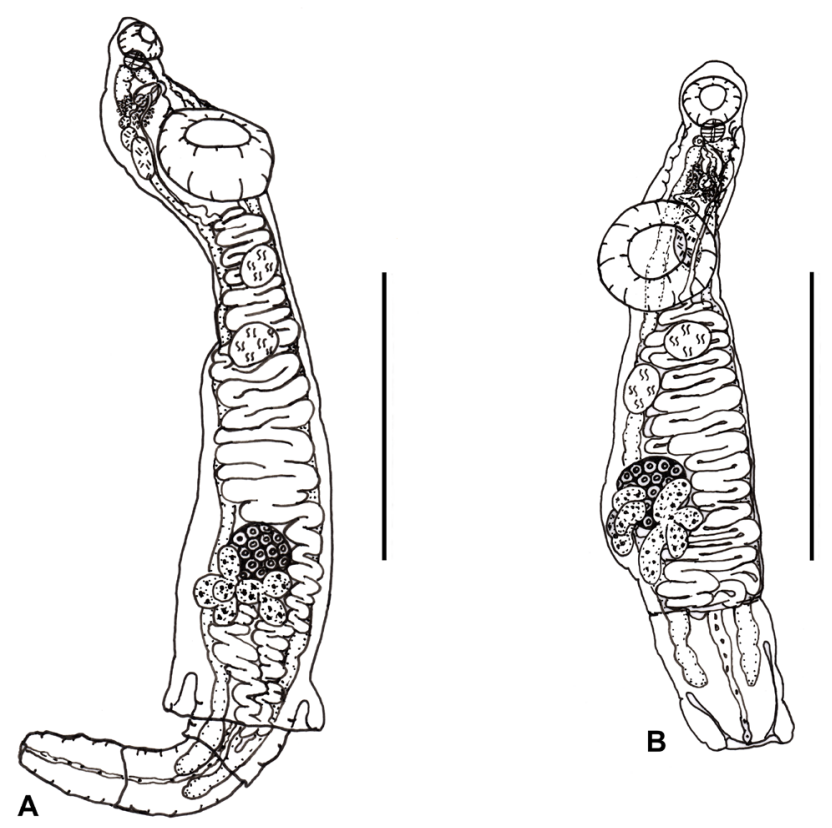

Figure 1. Lecithochirium monticellii from Trichiurus lepturus: a, Entire worm of one of the larger specimens, ventro-lateral view. $b$, Entire worm of one of the smaller specimens, ventro-lateral view. Scale bars: $\mathbf{a}=1 \mathrm{~mm}$ and $b=0.5 \mathrm{~mm}$.

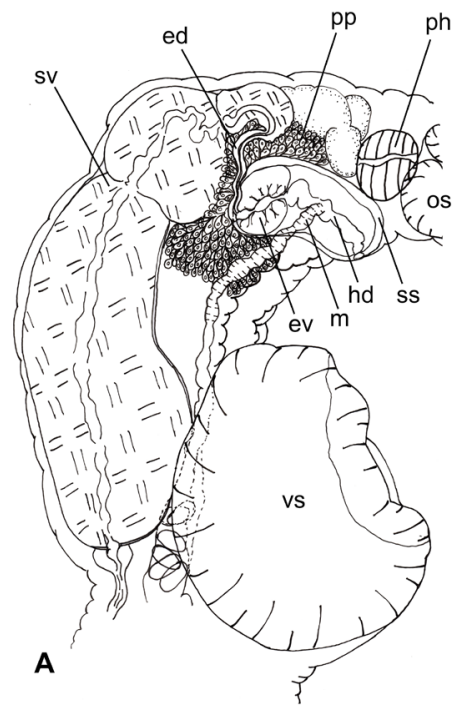

Taxonomic summary

- Host: Trichiurus lepturus.

- Localities: municipalities of Niterói and Cabo Frio, RJ, Brazil.

- Number of collected specimens: 929.

- Prevalence: $71.6 \%$.

- Mean intensity: 21.26.

- Mean abundance: 15.48 .

- Range of infection: 1 to 125 specimens by host.
Figure 2. Lecithochirium monticellii from Trichiurus lepturus. Detail of terminal genitalia showing seminal vesicle (sv), ejaculatory duct (ed), pars prostatica (pp), ejaculatory vesicle (ev), sinus sac (ss), hermaphroditic duct (hd), metraterm (m), pharynx (ph), oral sucker (os) and ventral sucker (vs). a, Seminal vesicle completely filled with semen. b, Seminal vesicle not completely filled with semen and ejaculatory duct swollen in its median and distal portion. Scale bar $=0.4 \mathrm{~mm}$.
- Infection sites: stomach and intestine.

- Material deposited: CHIOC n. 40008a- C, 40009a- d, 40010a, b, 40011, 40012, 40013a, b, 40014a-f, 40015.

- Material examined: L. manteri in T. lepturus (CHIOC 30557, 33452); L. microstomum (in T. lepturus CHIOC 32245 , Oligoplites palometa CHIOC 33616, Caranx latus CHIOC 34316, Micropogonias furnieri CHIOC 34014, Paralonchurus brasiliensis 
CHIOC 36208, Cynocion guatucupa CHIOC 36355); L. monticelli (in Trachurus lathami CHIOC 32121, 32122), L. perfidum (in Scomber colias CHIOC 30745); L. texanum (in Selene vomer CHIOC 31070).

\section{DISCUSSION}

The morphology and morphometry of the specimens of L. monticelli of the present study are in accordance with the specimens descried by Linton (1940), Skrjabin \& Guchankaja (1955), Nasir \& Diaz (1971) and Fernandes et al. (1985)

Lecithochirium monticellii was described by Linton (1898) as Distomum monticellii from Remora remora at Woods Hole, Massachusetts, USA. Later, Lühe (1901) created the genus Lecithochirium. Skrjabin \& Guchankaja (1955) reviewed the existing species of Lecithochirium and listed D. monticellii, Hemiurus monticelllii (Linton 1898) Looss 1899 and Sterrhurus monticellii (Linton 1898) Linton 1910, as synonyms, as previously suggested by Crowcroft (1946).

The species has been reported from some species of fish from off the coast of South America, including Echeneis naucrates Linnaeus 1758 for Argentina, T. lepturus for Venezuela and Trachurus lathami Nichols 1920 for Brazil. This is the first report of L. monticellii in T. lepturus for Brazil.

According to Nasir \& Diaz (1971) and Bray (1991) the genus Lecithochirium contains about 100 nominal species, including morphologically and morphometrically closely related species, some of which have been synonimized. It should be noted that when describing L. microstomum from T. lepturus from Galveston Bay, Texas, USA, Chandler (1935) pointed out that the species Distomum monticellli could be a species of Lecithochirium, and that it could even be the same that he had described: "...although some of the forms referred by Linton (1898, 1901, 1905) to Distomum monticelli may be species of Lecithochirium and may even be identical with the form here described. ...". In addition, all six species of Lecithochirium recorded parasitizing marine teleosteal fish in Brazil have morphological structures within the same size range, and $L$. manteri and $L$. microstomum have been recorded parasitizing $T$. lepturus (Kohn et al. 2007). Therefore, we suggest future studies aim to verify the validity of these species.

\section{Acknowledgments}

The authors would like to thank Bianca Huais Lourençone (Universidade Federal Fluminense) for help with fish necropsy, and Ricardo Baptista Schmidt (Serviço de Produção e Tratamento de Imagens do Instituto Oswaldo Cruz/FIOCRUZ) for processing the figures. This work was supported by fellowships from Coordenação de Aperfeiçoamento de Pessoal de Nivel Superior (CAPES, Finance Code 001); Fundação Carlos Chagas Filho de Amparo à Pesquisa do Estado do Rio de Janeiro (FAPERJ, E-26/202.072/2017), and Conselho Nacional de Desenvolvimento Científico e Técnológico (CNPq, grant numbers MCGF: 140093/2012-5 and 150140/2018-5; SCSC: 308048/2013-0).

\section{REFERENCES}

AL-ZUBAIDY A. 2010. First record of Lecithochirium sp. (Digenea: Hemiuridae) in the marine fish Carangoides bajad from the Red Sea, coast of Yemen. J KAU Mar Sci 21: 85-94.

BARROS GC \& AMATO JFR. 1993. Larvas de anisakídeos de peixe-espada, Trichiurus lepturus L., da costa do Estado do Rio de Janeiro, Brasil. Rev Bras Biol 53: 241-245.

BITTAR VT, CASTELO BFL \& DI BENEDITTO APM. 2008. Hábito alimentar do peixe-espada adulto, Trichiurus lepturus, na costa norte do Rio de Janeiro, sudeste do Brasil. Biotemas 21: 83-90.

BORGES JN, CUNHA LFG, MIRANDA DF, MONTEIRO-NETO C \& SANTOS CP. 2015. Molecular studies on larvae of Pseudoterranova parasite of Trichiurus lepturus Linnaeus, 1758 and Pomatomus saltatrix (Linnaeus, 1766) off Brazilian waters. Acta Parasitol 60: 649-653. 
BRAY RA. 1991. Hemiuridae (Digenea) from marine fishes of the southern Indian Ocean. Genus Lecithochirium Lühe, 1901 (Lecithochiriinae). Syst Parasitol 18: 193-219.

BUSH AO, LAFFERTY KD, LOTZ JM \& SHOSTAK AW. 1997. Parasitology meets ecology on its own terms: Margolis et al. Revisted. J Parasitol 84: 575-583.

CARVALHO AR \& LUQUEJL. 2009. Ocorrência de Neobenedenia melleni (Monogenea, Capsalidae) em Trichiurus lepturus (Perciformes, Trichiuridae), naturalmente infestados, no litoral do Rio de Janeiro, Brasil. Rev Bras Parasitol 18: 74-76.

CARVALHO AR \& LUQUE JL. 2011. Seasonal variation in metazoan parasites of Trichiurus lepturus (Perciformes, Trichiuridae) of Rio de Janeiro. Braz J Biol 71: 771-782.

CHANDLER AC. 1935. Parasites of fishes in Galveston Bay. Proc US Nat Mus 83: 123-157.

CHIOU WD, CHEN CY, WANG CM \& CHEN CT. 2006. Food and feeding habits of ribbonfish Trichiurus lepturus in coastal waters of south-western Taiwan. Fish Sci 72: 373-381.

CLAXTON AT, FUEHRING AD, ANDRES MJ, MONCRIEF TD \& CURRAN SS. 2017. Parasites of the Vermilion Snapper, Rhomboplites aurorubens (Cuvier), from the Western Atlantic Ocean. Comp Parasitol 84: 1-14.

CROWCROFT P. 1946. A description of Sterrhurus macrorchis n. sp., with notes on the taxonomy of the genus Sterrhurus Looss (Trematoda-Hemiuridae). Pap Proc R Soc Tasm 1945: 39-47.

FAO - FOOD AND AGRICULTURE ORGANIZATION OF THE UNITED NATIONS. 2005. Global Forest Resources Assessment. Rome: FAO Available at < www.fao.org/docrep/008/ a0400e/a0400e00.htm > Access: 15 Oct 2018.

FEKI M, CHÂARI M \& NEIFAR L. 2016. Spatial variability of helminth parasites and evidence for stock discrimination in the round sardinella, Sardinella aurita (Valenciennes, 1847), off the coast of Tunisia. J Helminthol 90: 353-358.

FERNANDES B, KOHN A \& PINTO RM. 1985. Aspidogastrid and digenetic trematodes parasites of marine fishes of the coast of Rio de Janeiro state, Brazil. Rev Brasil Biol 45: 109-116.

FIGUEIREDO LL \& MENEZES NA. 2000. Manual de peixes marinhos do sudeste do Brasil. VI. Teleostei (5). 1a ed., Museu de Zoologia de São Paulo, São Paulo, Brasil, p. 90.

GIBSON D, JONES A \& BRAY R. 2002. Keys to the Trematoda. Volume 1. CABI Publishing and the Natural History Museum. London, England, 544 p.
KNOFF M \& GOMES DC. 2012. Capítulo 3. Metodologia básica para coleta e processamento de helmintos parasitos. In: Molinaro E, Caputo L \& Amendoeira R (Eds), Conceitos e Métodos para formação de profissionais em laboratórios de saúde: volume 5. Ed. Escola Politécnica de Saúde Joaquim Venâncio, Fundação Oswaldo Cruz, Rio de Janeiro, 251-281 p.

KOHN A, FERNANDES BMM \& COHEN SC. 2007. South American Trematodes Parasites of Fishes. Imprinta Express Ltda, Rio de Janeiro, $318 \mathrm{p}$.

LINTON E. 1898. Notes on trematodes parasites of fishes. Proc US Nat Mus 20: 507-548.

LINTON E. 1901. Parasites of fishes of the Wood's Hole Region. Bull US Bur Fish 19: 405-492.

LINTON E. 1905. Parasites of fishes of Beaufort, North Carolina. Bull US Bur Fish 24: 321-428.

LINTON E. 1940. Trematodes from fishes mainly from the Woods Hole region, Massachusetts. Proc US Nat Mus 88: 1-172.

LÜHE M. 1901. Uber Hemiuriden. (Ein Beitrag zur Systematik der digenetischen Trematoden). Zoologischer Anzeiger 24: 394-403, 473-488.

MANTER H. 1934. Some digenetic trematodes from deep-water fish of Tortugas, Florida. Papers Tortugas Lab 28: 257-345.

MANTER HW. 1954. Some digenetic trematodes from fish of New Zealand. Trans Royal Soc N Zeal 82: 475-568.

MARTINS AS \& HAIMOVICI M. 1997. Distribution, abundance and biological interactions of the cutlassfish Trichiurus lepturus in the southern Brazil suptropical convergence ecosystem. Fish Res 30: 217-227.

MARTINS AS \& HAIMOVICI M. 2000. Reproduction of the cutlassfish Trichiurus lepturus in the southern Brazil subtropical convergence ecosystem. Sci Mar 64: 97-105.

MARTINS A, HAIMOVICI M, \& PALACIOS R. 2005. Diet and feeding of the cutlassfish Trichiurus lepturus in the subtropical convergence ecosystem of southern Brazil. J Mar Biol Assoc UK 85: 1223-1229.

MATTOS DPBG, VERÍCIMO MA \& SÃO CLEMENTE SC. 2013. O Pescado e os Cestoides Trypanorhyncha - Do Aspecto Higiênico ao potencial alergênico. Vet Not 19: 127-139.

MEYER M \& SMALE MJ. 1991. Predation patterns of demersal teleosts from the Cape south and west coasts of South Africa. 1. Pelagic predators. S Afr Jour Mar Sci 10: 173-191.

NAKAMURA I \& PARIN NV. 1993. FAO species catalogue. Vol. 15. Snake mackerels and cutlassfishes of the world (families Gempylidae and Trichiuridae). An annotated and illustrated catalogue of the snake mackerels, 
snoeks, escolars, gemfishes, sackfishes, domine, oilfish, cutlassfishes, scabbardfishes, hairtails, and frostfishes known to date. FAO Fisheries Synopis, 136 p.

NASIR P \& DÍAZ M. 1971. Digenetic trematodes from Venezuelan marine fishes. Rev Parasitol 32: 53-73.

SÃO CLEMENTE SC, MARQUES MC, FREIRE NMS \& LUCENA FP. 1995. Análise do parasitismo de Peixe Espada Trichiurus lepturus (L.) do litoral do Rio de Janeiro. Parasitol Día 19: 146-149.

SHIH HH, LIU W \& ZHAO ZQ. 2004. Digenean fauna in marine fishes from Taiwanese water with the description of a new species Lecithochirium tetraorchis sp. nov. Zool Stud 43: 671-676.

SILVA LO, ALVES DR, LUQUE JL \& PARAGUASSÚ AR. 2000a. Ecologia da comunidade de metazoários parasitos do Peixe-Espada Trichiurus lepturus Linnaeus (Osteichthyes, Trichiuridae) do litoral do Estado do Rio de Janeiro, Brasil. Rev Bras Zoo 2: 115-133.

SILVA LO, ALVES DR \& LUQUE JL. 2000b. Metazoários parasitos do Peixe-Espada Trichiurus lepturus Linnaeus (Osteichthyes, Trichiuridae) do litoral do Estado do Rio de Janeiro, Brasil. Parasitol Día 24: 97-101

SKRJABIN KI \& GUSCHANSKAJA LK. 1955. In Skrjabin KI (Ed), Trematodes of animals and man. Moscow 13: 725-783.

YAMAGUTI S. 1971. Synopsis of the digenetic trematodes of vertebrates. Volumes.1 \& 2. Keigaku Publishing Co. Tokyo, Japan, $1423 \mathrm{p}$.

\section{How to cite}

FRANÇA LF, KNOFF M, FONSECA MCG, GOMES DC, FERREIRA MS, FELIZARDO NN, SÃO CLEMENTE SC \& MATOS DPBG. 2020. Lecithochirium monticellii digenetic trematode parasites of Trichiurus lepturus (Actinopterygii) from the state of Rio de Janeiro, Brazil, with notes on its taxonomy. An Acad Bras Cienc 92: e20190161. DOI 10.1590/0001-3765202020190161.

Manuscript received on February 14, 2019;

accepted for publication on May 7, 2019

LUMA F. FRANÇA ${ }^{1}$

https://orcid.org/0000-0001-7462-8966

MARCELO KNOFF ${ }^{2}$

https://orcid.org/0000-0003-1934-5642

MICHELLE C.G. DA FONSECA ${ }^{2}$

https://orcid.org/0000-0003-2630-2149

DELIR C. GOMES ${ }^{2}$

https://orcid.org/0000-0003-1513-7571

\section{MICHELI S. FERREIRA ${ }^{3}$}

https://orcid.org/0000-0002-1109-8897

NILZA N. FELIZARDO ${ }^{3}$

https://orcid.org/0000-0002-1887-9549

\section{SÉRGIO C. DE SÃO CLEMENTE ${ }^{3}$}

https://orcid.org/0000-0002-5791-3615

\section{DANUZA P.B.G. DE MATTOS ${ }^{1}$}

https://orcid.org/0000-0002-0947-8743

${ }^{1}$ Universidade Federal Fluminense/UFF, Programa de Pós-graduação em Microbiologia e Parasitologia Aplicadas, Departamento de Microbiologia e Parasitologia, Instituto Biomédico, Rua Hernani de Mello, 101, São Domingos, 24210-130 Niterói, RJ, Brazil

${ }^{2}$ Fundação Oswaldo Cruz/FIOCRUZ, Laboratório de Helmintos Parasitos de Vertebrados, Instituto Oswaldo Cruz, Avenida Brasil, 4365, Manguinhos, 21040-900 Rio de Janeiro, RJ, Brazil

${ }^{3}$ Universidade Federal Fluminense/UFF, Laboratório de Inspeção e Tecnologia de Pescado, Rua Vital Brazil Filho, 64, Vital Brazil, 24230-340 Niterói, RJ, Brazil

Correspondence to: Danuza Pinheiro Bastos Garcia de Mattos E-mail:danuzamattos@id.uff.br

\section{Author contributions}

All authors presented relevant contribution in the manuscript. Luma França was responsable for data sampling, analysis, literature review and manuscript writing; Dr Michelle CG Fonseca, Dr Delir C Gomes, Dr Nilza N Felizardo and Dr Sérgio São Clemente contributed to the analysis and interpretation of data for identification and taxonomy. Dr Marcelo Knoff contributed for identification, taxonomy, and prepared the figures. Dr Micheli S. Ferreira was academic co-advisor and contributed with critical revision of the manuscript. Dr Danuza PBG Mattos was academic advisor and project supervisor, responsible for study conception, design and revision of the manuscript.

\section{(cc) BY}

